\title{
ANALISIS TINGKAT KEMAMPUAN PEMECAHAN MASALAH MATERI FLUIDA STATIS MELALUI MODEL PEMBELAJARAN PROBLEM SOLVING
}

\section{ANALYSIS OF STUDENT PROBLEM SOLVING LVEL IN STATIC FLUID TOPIC THROUGH PROBLEM SOLVING LEARNING MODEL}

\author{
I Wayan Gunada ${ }^{1}$, Yona Roswiani ${ }^{2}$ \\ ${ }^{1}$ Program Studi Pendidikan Fisika, Jurusan Pendidikan MIPA, Fakultas Keguruan dan Ilmu Pendidikan, \\ Universitas Mataram \\ ${ }^{2}$ Sekolah Menengah Atas Negeri 2 Mataram, Kota Mataram, Nusa Tenggara Barat. \\ *E-mail: wayan gunada@unram.ac.id.
}

Diterima: 08 Januari 2019. Disetujui: 02 Maret 2019. Dipublikasikan: 31 Maret 2019

\begin{abstract}
Abstrak: Penelitian ini bertujuan untuk menganalisis kemampuan pemecahan masalah (KPM) peserta didik pada materi fluida statis. Kemampuan pemecahan masalah ini diujikan pada pokok bahasan tekanan hidrostatis, hukum Pascal, hukum Archimedes, dan viskositas. Subjek penelitian ini sebanyak 35 siswa kelas XI IPA 6 SMA Negeri 2 Mataram. Metode yang digunakan dalam penelitian ini metode analisis deskriptif. Hasil penelitian menunjukan bahwa pada pertemuan pertama skor rata-rata KPM pada materi tekanan hidrostatis sebesar 70 (kategori sedang), pertemuan kedua skor rata -rata KPM pada materi hukum Pascal sebesar 71,43 (kategori sedang), pertemuan ketiga skor rata-rata KPM pada materi hukum Archimedes sebesar 75,14 (kategori tinggi), dan pertemuan keempat skor rata -rata KPM pada materi viskositas sebesar 80,57(kategori tinggi). Secara umum adanya peningkatan KPM yang ditunjukan oleh peserta didik setelah mengikuti proses pembelajaran dengan model problem solving. Ditinjau dari indikator kemampuan pemecahan masalah (KPM), ternyata indikator memahami masalah (IPM-1)memperoleh skor rata-rata 78.57, menyusun rencana (IPM-2) memperoleh skor rata-rata76,77, melaksanakan rencana ( IPM-3) memperoleh skor rata-rata 79,04, dan indikator mengecek kembali hasil pekerjaan(IPM-04) memperoleh skor rata-rata sebesar 58,57.
\end{abstract}

Kata kunci: fluida statis, pemecahan masalah

\begin{abstract}
The aim of this research is to analyze the students' problem solving capability in static fluid subject. This problem solving capability was tested in several subjects, such as hydrostatic pressure, the pascal law, the Archimedes law and viscocity. The subjects of this research are 35 students of XI IPA 6, Senior High School 2 Mataram. The method of this research is descriptive analysis. The result of this research showed that at first meeting of the class, the score of the problem solving capability in hydrostatic pressure subjets is 70 (medium category), the second meeting score in the subject of the Pascal Law is 71.43 (medium category), then on the third meeting in the subject of viscocity, the score is 80.57 (high score category). The conclusion of the problem solving method was it can increase the capability of the student in solving the problem of the subject they learn. There are some indicators put to see capability of problem solving and each of them got their own scores. The indicator of unserstanding the problem got score in the average of 78.57, planning was scored at the average of 76.77, implementing the plan got score at the average of 79.04 and at the indicator of checking the result, it scored at the average of 58.57 .
\end{abstract}

Keywords: static fluid, problem solving

\section{PENDAHULUAN}

Pembelajaran fisika bertujuan membekali peserta didik berupa pengetahuan, pemahaman, dan kemampuan berpikir tingkat tinggi [1]. Pemahaman yang baik ditujukan agar peserta didik mampu memecahkan suatu masalah kompleks berdasarkan kemampuan memahami suatu informasi. Pemahaman yang utuh dapat menjadi bekal yang baik bagi peserta didik dalam memecahkan masalah. Penerapannya yang luas pada berbagai bidang keilmuan dan teknologi menuntut pembelajaran di sekolah agar mampu membekali peserta didik dengan kemampuan pemahaman fisika yang lebih kuat. Pembelajaran fisika tidak hanya terfokus pada hasil belajar, menghafal sejumlah fakta, dan konsep, akan tetapi lebih dari itu, yaitu memiliki kemampuan pemecahan masalah fisika [2-8]. Sesuai dengan kurikulum 2013, salah satu bagian dari materi fisika SMA kelas XI adalah materi fluida statis. Secara definisi kata fluid yang dapat diartikan sebagai zat alir atau zat yang memiliki sifat dapat mengalir. Statika fluida merupakan pembahasan fenomena fluida diam [9]. Fluida statis merupakan bagian dari ilmu fisika yang erat kaitannya dengan dengan fenomena alam. Materi fluida statis mencakup hukum tekanan Hidrostatis, Hukum Pascal, Hukum Archimedes (tenggelam, melayang, terapung), peristiwa kapilaritas, dan tegangan permukaan. Kompetensi 
dasar yang ingin dicapai dalam pembelajaran fluida statis di sekolah menengah antara lain: 1)menerapkan hukum-hukum fluida statik dalam kehidupan sehari-hari, dan 2) merancang dan melakukan percobaan yang memanfaatkan sifat-sifat fluida statik, berikut presentasi hasil percobaan dan pemanfaatannya. Permasalahan mendasar yang dialami peserta didik dalam memahami materi fluida statis adalah peserta didik lebih sering menerima materi dan persamaan-persamaan tanpa melakukan proses penemuan sendiri suatu konsep fisika dan cenderung menghafalkan setiap rumus yang diberikan oleh guru tanpa memaknai makna fisis dari rumus tersebut [10]. Penguasaan konsep fluida statis paling lemah dikuasai oleh siswa. Jika masalah ini terus-menerus berkelanjutan dalam mengajarkan materi fluida statis, maka peserta didik akan mengalami kegagalan dalam memahami suatu konsep yang nantinya akan berdampak pada peserta didik dalam memecahkan suatu permasalah yang berhubungan dengan masalah sehari-hari. Selain itu pada kenyataannya proses pembelajaran konsep fluida statis di sekolah masih didominasi oleh metode pembelajaran yang cenderung bersifat informatif dan lebih ditekankan pada perumusan persamaan matematis sehingga kurang memberikan pengalaman nyata pada siswa dalam berinteraksi langsung dengan fenomena fluida statis yang dipelajari [11].

Berbagai penelitian pada materi fluida statis maupun dinamis telah banyak dilakukan. Hasil penelitian mengungkapkan bahwa peserta didik kesulitan dalam mengidentifikasi masalah secara tepat, karena tidak menggunakan konsep yang benar. Sedangkan hasil penelitian [11] menunjukan bahwa kemampuan pemecahan masalah siswa kelas XI IPA, tergolong sangat rendah. Rendahnya kemampuan pemecahan masalah disebabkan oleh implementasi model pembelajaran yang kurang tepat. Bertitik tolak dari hal tersebut di atas, diperlukan suatu model pembelajaran yang dapat meningkatkan kemampuan pemecahan masalah. Problem solving adalah suatu model pembelajaran dengan pemecahan persoalan [12]. Pemecahan masalah (Problem Solving) merupakan salah satu alat utama dalam pengajaran fisika. Sebagai suatu alat, pemecahan masalah digunakan untuk memperdalam pemahaman konsep-konsep dan prinsip-prinsip utama, dan membantu peserta didik untuk menerapkan konsepkonsep dan prinsip-prinsip itu pada berbagai persoalan.

Model problem solving membantu peserta didik untuk mengatasi salah pengertian dalam memahami materi pelajaran fisika. Dalam praktek, pembelajaran fisika selalu dimulai dengan penjelasan materi pelajaran dengan berbagai metode dan strategi pembelajaran yang sesuai, kemudian disertai dengan contoh-contoh pemecahan masalah, dan diakhiri dengan latihan memecahkan masalah baik di kelas maupun rumah. Permasalahanpermasalahan yang disajikan pengajar umumnya berasal dari buku teks. Permasalahan-permasalahan itu biasanya dalam bentuk kuantitatif dan hanya meminta satu macam solusi. Penggunaan model problem solving diharapkan dapat mempermudah guru untuk menghasilkan peserta didik yang kompeten dalam bidang ilmu pengetahuan khususnya fisika [13].

Terdapat ada 5 langkah pembelajaran problem solving yaitu: (1) pemahaman masalah, (2) menampilkan masalah secara fisika, (3) merencanakan strategi pemecahan, (4) menjalankan rencana, dan (5) evaluasi dan perluasan. Pemilihan metode pembelajaran problem solving dikarenakan metode ini dapat memingkat kemampuan pemecahan masalah, yang berakibat pada meningkatnya hasil belajar [14].

Indikator kemampuan pemecahan masalah (KPM) dapat diklasifikasikan menjadi empat, yaitu kemampuan memahami masalah, kemampuan merencanakan solusi, kemampuan melaksanakan penyelesaian, dan mengecek kembali. KPM adalah kemampuan dasar yang dimiliki peserta didik untuk menemukan solusi yang tepat dari permasalahan-permasalahan yang diberikan berkaitan dengan materi pembelajaran dengan menggunakan penalaran dan berpikir tingkat tinggi [15].

Kesulitan peserta didik dalam memecahkan permasalahan fisika lebih banyak disebabkan oleh kurangnya latihan dan kurangnya pembiasaan pemberian soal pemecahan masalah. Pemecahan permasalahan yang baik, hendaknya disusun permasalahan konstektual yang berhubungan dengan kehidupan sehari-hari siswa. Peneliti telah melakukan penelitian dengan menganalisis kemampuan peserta didik dalam memecahkan permasalahan fisika pada materi fluida statis. Materi fluida statis dipilih dalam penelitian ini karena masih banyak ditemukan kesulitankesulitan yang dialami peserta didik dalam memahami materi ini khususnya pokok bahasan tekanan hidrostatis, hukum Pascal, hukum Archimedes dan viskositas. Dengan menganalisis kemampuan pemecahan masalah fisika, peneliti dapat menemukan kesulitan yang dihadapi oleh peserta didik serta mengetahui kemampuan pemecahan masalah yang dimiliki oleh peserta didik [16].

\section{METODE PENELITIAN}

Penelitian ini merupakan penelitian deskriptif kuantitatif karena kegiatan utama dalam penelitian ini yaitu mendeskripsikan tingkat kemampuan pemecahan masalah (KPM) peserta didik kelas XI IPA 6 SMA Negeri 2 Mataram. KPM pada saat pembelajaran diukur dengan memberikan tes pada peserta didik tentang materi fluida statis. Tesnya berupa soal uraian pada setiap pertemuan. Setiap 
pertemuan membahas masing-masing sub pokok materi tekanan hidrostatis, hukum Pascal, hukum Archimedes dan viskositas. Tingkat kemampuan pemecahan masalah, dianalisis menggunakan statistik deskriptif.

\section{HASIL DAN PEMBAHASAN}

Penelitian ini bertujuan untuk menganalisis tingkat kemampuan pemecahan masalah yang dialami peserta didik SMAN 2 Mataram Kelas XI IPA 6 pada materi fluida statis. Data kemampuan pemecahan masalah peserta didik pada keempat pertemuan dapat dijabarkan pada Tabel 1.

Tingkat kemampuan pemecahan masalah yang diukur berdasarkan empat indikator, yaitu kemampuan memahami masalah, kemampuan merencanakan solusi, kemampuan melaksanakan penyelesaian, dan mengecek kembali. Proses enilaian dilaksanakan pada setiap pertemuan dengan empat kali pertemuan yang membahas empat sub materi pokok fluida statis, yaitu tekanan hidrostatis, hukum Pascal, hukum Archimedes, dan viskositas.

Hasilnya menunjukan bahwa, pada pertemuan pertama dengan pokok bahasan tekanan hidrostatis skor KPM memberikan hasil yang paling rendah yaitu 70,00 (kategori sedang), hal ini disebabkan karena peserta didik masih kebingungan dan belum mengetahui tahapan-tahapan yang dilakukan di awal proses pembelajaran. Tujuan utama dari pembelajaran ini antara lain : mengetahui prinsip tekanan hidrostatis dan menganalisis faktor-faktor yang mempengaruhi tekanan hidrostatis. Diawal pembelajaran semua peserta didik, di beri pertanyaan lewat gambar. Keempat gambar tersebut, memperlihatkan gambar wadah yang berisi zat cair dengan luasan yang berbeda - beda, dan terdapat titik dengan ketinggian yang bervariasi. Kemudian peserta didik disuruh memilih salah satu dari keempat gambar tersebut, manakah dari keempat titik pada gambar tersebut yang memiliki tekanan yang paling besar. Pada akhirnya, peserta didik memahami bahwa faktor yang mempengaruhi tekanan hidrostatis berawal dari gaya berat zat cair

$P=\frac{w}{A}=\frac{m g}{A}=\frac{\rho V g}{A}=\frac{\rho A h g}{A}$

dan kemudian tekanan hidrostatis dirumuskan $P=\rho g h$. Kemudian pada pertemuan berikutnya dengan pokok bahasan yang berbeda skor KPM sudah mengalami peningkatan, hal ini disebabkan karena peserta didik sudah dilatih mengerjakan tahapan-tahapan kemampuan pemecahan masalah. Kemampuan pemecahan masalah yang dilatih selama proses pembelajaran di dalam kelas tentunya berdampak secara langsung terhadap tes evaluasi berikutnya. Peserta didik yang sering melatihkan kemampuan pemecahan masalah akan memberikan penjelasan yang lebih baik dalam menjawab suatu permasalahan. Selain itu yang menyebabkan rendahnya KPM diawal disebabkan oleh, kemampuan guru beradaptasi dengan peserta didik dan bagaimana menemukan cara yang terbaik untuk menyampaikan berbagai konsep yang diajarkan sehingga peserta didik dapat menggunakan dan mengingat lebih lama konsep tersebut. Di awal pembelajaran inilah perlunya mengetahui karakteristik peserta didik.

Kemudian pada tahapan berikutnya, pada materi hukum Pascal, hukum Archimedes, dan viskositas, KPM peserta didik sudah mengalami peningkatan. Terlihat pada pokok bahasan viskositas, skor rata-ratanya mencapai 80,57 (kategori tinggi). Hal ini sebagai dampak dari implementasi model pembelajaran problem solving pada pembelajaran fisika yang berimplikasi pada motivasi, kemampuan pemecahan masalah dan hasil belajar [17].

Tabel 1 Skor Tingkat Kemampuan Pemecahan Masalah Peserta Didik Kelas XI IPA 6 SMA Negeri 2 Mataram.

\begin{tabular}{|c|c|c|c|c|c|c|c|}
\hline \multirow{2}{*}{$\begin{array}{l}\text { Per } \\
\text { Ke- }\end{array}$} & \multirow[t]{2}{*}{ Materi } & \multicolumn{4}{|c|}{ Tingkat KPM } & \multirow{2}{*}{ Rata-rata } & \multirow{2}{*}{ Kategori } \\
\hline & & IPM-1 & IPM-2 & IPM-3 & IPM-4 & & \\
\hline 1 & Tekanan Hidrostatis & 78,57 & 77,57 & 72,86 & 47,14 & 70,00 & $\mathrm{~S}$ \\
\hline 2 & Hukum Pascal & 75,71 & 77,14 & 77,14 & 50,00 & 71,43 & $\mathrm{~S}$ \\
\hline 3 & Hukum Archimedes & 78,57 & 74,29 & 79,71 & 65.71 & 75,14 & $\mathrm{~T}$ \\
\hline 4 & Viskositas & 81,43 & 77,14 & 86,43 & 71,43 & 80,57 & $\mathrm{~T}$ \\
\hline
\end{tabular}

Keterangan: IPM-1: Pemahaman masalah; IPM -2: Merencanakan solusi; IPM -3: Melaksanakan penyelesaian dan IPM -4: Memeriksa kembali. Kriteria Penilaian: Sangat Tinggi (ST): 86 - 100; Tinggi (T): 75 - 85; Sedang (S): 60 - 74; Kurang (K): nilai $<60$

Uraian dari kegiatan masing-masing indikator dapat dijabarkan sebagai berikut:

\section{A. Menganalisis Masalah}

Adapun tujuan dari kegiatan ini adalah memperoleh suatu gambaran yang lengkap suatu masalah mengenai apa yang diketahui dan apa yang ditanyakan. Dengan demikian peserta didik akan terhindar dari memecahkan masalah sebelum mengerti betul apa yang ditanyakan. Kegiatankegiatan yang dilakukan pada tahap ini antara lain:

(1) Membaca permasalahan atau soal secara hatihati. Identifikasi kata-kata kunci dan hubunganhubungannya, identifikasi setiap kata atau 
kalimat yang dapat memberi petunuk pada suatu solusi.

(2) Mengidentifikasi pertanyaan-pertanyaan yang akan dijawab yang disesuaikan dengan konsepkonsep fluida statis yang terlibat dalam permasalahan itu.

(3) Visualisasi masalah yakni menerjemahkan masalah dalam deskripsi fisika, menggambarkan sketsa (sekumpulan sketsa) suatu situasi masalah.

(4) Tuliskan kuantitas yang diketahui dan ditanyakan.

(5) Hubungkan persamaan-persamaan yang sesuai dengan masalah yang dihadapi Identifikasi apakah bagian-bagian solusi memerlukan konversi satuan atau tidak.

\section{B. Merencanakan Rencana Penyelesaian}

Pada tahap ini kegiatan yang dilakukan adalah memikirkan hubungan-hubungan dan informasi yang mengkaitkan antara informasi yang diberikan dan yang ditanyakan. Adapun kegiatan yang dilakukan meliputi : (1) membuat garis besar (out line) infromasi yang dapat menjawab pertanyaan-pertanyaan dalam soal, (2) identifikasi konsep-konsep dan prinsip-prinsip utama yang dapat digunakan untuk menjawab soal, (3) buat pokokpokok pikiran jawaban permasalahan (soal), (4) uraikan pokok-pokok pikiran itu menjadi lebih detail dan dukung dengan contoh-contoh, (5) terjemahkan deskripsi fisika ke dalam representasi matematik yang tepat, (6) memulai dengan konsepkonsep dan prinsip-prinsip yang teridentifikasi dalam bentuk persamaan. Strategi yang beragam, sangat diperlukan dalam memecahkan permasalahan-permasalahan yang kompleks [18]

\section{Mengerjakan Rencana Solusi}

Pada tahap ini, kegiatan yang dilakukan adalah mengerjakan penyelesaian menurut rencana dalam bentuk deskripsi dan perhitungan-perhitungan matematik. Untuk permasalahan kualitatif, jawaban permasalahan mengandung tiga bagian yaitu kalimat pendahuluan, inti paparan, dan kesimpulan. Kemudian disarankan hal-hal berikut : (1) mulailah dengan pernyataan-pernyataan pendahuluan dengan menyatakan kembali pertanyaan dan menunjukkan bagaimana memulai menjawab pertanyaan tersebut, dan gunakan aturan-aturan matematik untuk mendapatkan ungkapan-ungkapan dari variabel yang tak diketahui dan semua variabel yang diketahui pada sisi lain suatu persamaan, kemudian memasukkan nilai-nilai spesifik ke dalam ungkapan tersebut untuk mendapatkan solusi numeriknya.

\section{Mengecek Kembali Hasil Pekerjaan .}

Pada tahap ini merupakan tahap akhir dari pemecahan masalah. Peserta didik diminta untuk mencek solusi masalah. Apakah jawaban itu masuk akal? Apakah perhitungan-perhitungan sudah benar?
Apakah besaran satuan yang ditulis sudah benar ? Apakah semua pertanyaan sudah terjawab?

Di atas telah ditunjukkan skor penguasaan peserta didik terhadap materi fluida statis yang diajarkan, sekaligus menggambarkan kemampuan memecahkan masalah (problem solving) secara umum. Pada bagian ini kemampuan memecahkan masalah akan ditampilkan atas komponenkomponennya yaitu menganalisis masalah, merencanakan solusi, menyelesaikan solusi, dan mengecek kembali hasil pekerjaan. Dari tabel tersebut dapat dilihat bahwa, indikator memahami masalah (IPM-1) memperoleh skor rata-rata 78.57, merencanakan solusi (IPM-2) memperoleh skor rata-rata76,77, melaksanakan rencana penyelesaian (IPM-3) memperoleh skor rata-rata 79,04, dan indikator mengecek kembali hasil pekerjaan (IPM04) memperoleh skor rata-rata sebesar 58,57 .

Berdasarkan hasil pengamatan pada proses pembelajaran, menunjukkan bahwa sekitar bahwa peserta didik mengalami perubahan cara belajar dari menghafal rumus-rumus, kemudian mencocokkan dengan soal yang dihadapi menjadi belajar dari konsep/prinsip fluida statis, kemudian digunakan dalam merencanakan solusi dari suatu masalah yang dihadapinya. Hal ini tampak konsisten dengan skor salah satu aspek pemecahan masalah yaitu merencanakan solusi. Berdasarkan pengamatan pada lembar pekerjaan peserta didik terlihat bahwa dalam merencanakan solusi suatu masalah, pada umumnya peserta didik menuliskan konsep-konsep atau prinsip-prinsip yang akan digunakan untuk memecahkan masalah yang dihadapinya. Skor terendah diperoleh dari indikator mengecek kembali hasil pekerjaan, yang memberikan skor 58,57, hal ini disebakan karena peserta didik terburu -buru mengumpulkan hasil pekerjaanya dan tidak memeriksa kembali hasil pekerjaannya. Kesalahan yang dijumpai, lebih banyak pada tidak menuliskan satuan dari besaran yang diperoleh. Tahap logical progession, seluruh peserta didik bernilai nol, karena peserta didik terbiasa tidak memeriksa atau mengecek kembali apakah seluruh solusi masalahnya jelas, logis, fokus dan terorganisir.

\section{KESIMPULAN}

Kemampuan pemecahan masalah peserta didik berdasarkan masing-masing indikator meliputi memahami masalah memperoleh skor rata-rata 78.57 (kategori tinggi), merencanakan solusi memperoleh skor rata-rata76,77 (kategori tinggi), melaksanakan rencana penyelesaian memperoleh skor rata-rata 79,04 (kategori tinggi), dan indikator mengecek kembali hasil pekerjaan memperoleh skor rata-rata sebesar 58,57 (kategori kurang).

\section{UCAPAN TERIMA KASIH}

Penulis mengucapkan terima kasih kepada Fakultas Keguruan dan Ilmu Pendidikan lewat dana hibah Penugasan Dosen di Sekolah (PDS) Tahun 2018 


\section{DAFTAR PUSTAKA}

[1] Makrufi, A., Hidayat, A., Muhardjito., Sriwati, E. 2016. Analisis Kemampuan Pemecahan Masalah Siswa Pada Materi Fluida Dinamis. Prosiding Seminar Nasional Pendidikan 2016. Peran Pendidikan, Sains, dan Teknologi dalam Membangun Intelektual Bangsa dan Menjaga Budaya Nasional di Era MEA

[2] Wena, M. 2014. Strategi Pembelajaran Inovatif Kontemporer. Jakarta Timur: PT Bumi Aksara.

[3] Gunada, I. W., Sahidu, H., \& Sutrio, S. (2017). Pengembangan Perangkat Pembelajaran Fisika Berbasis Masalah untuk Meningkatkan Hasil Belajar dan Sikap Ilmiah Mahasiswa. Jurnal Pendidikan Fisika dan Teknologi, 1(1), 38-46.

[4] Wijayanti, A. (2016). Implementasi model pembelajaran kooperatif tipe tgt sebagai upaya meningkatkan pemahaman konsep fisika dasar mahasiswa pendidikan IPA. Jurnal Pijar Mipa, 11(1).

[5] Al-idrus, S. Q. M. J., Hikmawati, H., \& Wahyudi, W. (2015). Pengaruh model pembelajaran berbasis masalah berbantuan video kartun terhadap hasil belajar fisika siswa kelas xi sman 1 sikur tahun ajaran 2014/2015. Jurnal Pijar MIPA, 10(1).

[6] Amanah, P. D., Harjono, A., \& Gunada, I. W. (2017). Kemampuan Pemecahan Masalah Dalam Fisika Dengan Pembelajaran Generatif Berbantuan Scaffolding dan Advance Organizer. Jurnal Pendidikan Fisika dan Teknologi, 3(1), 84-91.

[7] Tamami, F., Rokhmat, J., \& Gunada, I. W. (2017). Pengaruh pendekatan berpikir kausalitik scaffolding tipe 2a modifikasi berbantuan LKS terhadap kemampuan pemecahan masalah optik geometri dan kreativitas siswa kelas XI SMAN 1 Mataram. Jurnal Pendidikan Fisika dan Teknologi, 3(1), 76-83.

[8] Yuliana, I., Rokhmat, J., \& Gunada, I. W. (2017, November). Pengaruh Berpikir Kausalitik Ber-Scaffolding Terhadap Kemampuan Pemecahan-Masalah Kalor pada Siswa SMA. In Prosiding SNFA (Seminar Nasional Fisika dan Aplikasinya) (Vol. 2, pp. 85-92).

[9] Rokhmat, J. 2017. Fisika Dasar Pendekatan Berpikir Kausalistik.Mataram: Arga Puji Press.

[10] Purnamasari, I., Yuliati, L., Diantoro. M. 2017. Analisis Kemampuan Pemecahan Masalah Fisika Pada Materi Fluida Statis . Prosiding Seminar Nasional Pasca Sarjana $U M$.

[11] Aini, N N., Kusairi, S., Diantoro, M. 2017. Penguasaan Konsep Fluida Statis Dalam
Pembelajaran Kolaboratif Dengan Penilaian Formatif. Jurnal Pendidikan: Teori, Penelitian, dan Pengembangan, 2(10):13771387.

[12] Suparno, P. 2013. Miskonsepsi Perubahan Konsep dalam Pendidikan Fisika. Jakarta: Gramedia Widiasarana Indonesia.

[13] Hutabarak, G.D. \& Sahyar. 2013. Efek Model Pembelajaran Problem Solving dan Motivasi Terhadap Hasil Belajar Fisika Siswa SMA. Jurnal Pendidikan Fisika, 2(2) :65-72.

[14] Warimun, E.S. 2012. Penerapan Problem Solving Fisika Pada Pembelajaran Topik Optika Pada Mahasiswa Pendidikan Fisika.Jurnal Excata, 10 (2) :111-114.

[15] Selcuk, G. S., Caliskan, S., and Erol, M. 2008. The Effect Of Problem Solving Instruction on Physics Achiement, Problem Solving Performance and Strategiy Use. American Journal of Physics Education, 2(3): 151-165.

[16] Sijabat A, Motlan, Derlina. 2016. Pengaruh Model Pembelajaran Problem Solving dan Pemahaman Konsep Terhadap Hasil Belajar Fisika Siswa. Jurnal Pendidikan Fisika, 5(2). 87-91.

[17] Rahono, D., Sunarno,W., Cari. 2014 Pembelajaran Fisika dengan Pendekatan Problem Solving Melalui Metode Demonstrasi dan Eksperimen untuk meningkatkan Motivasi dan Hasil Belajar Fisika. Jurnal Inkuiri, 3 (3):75-85.

[18] Fadillah,S. 2009. Kemampuan Pemecahan Masalah Matematis dalam Pembelajaran Matematika. Prosiding Seminar Nasional Penelitian, Pendidikan dan Penerapan MIPA FakultasMIPA Universitas Negeri Yogyakarta 